\title{
Introduction
}

\author{
Rory Naismith
}

This volume is about ways of studying medieval money, and especially the most direct manifestation of money: coinage. It is intended to introduce readers to a range of approaches to a subject that has traditionally been seen as somewhat specialized; a domain of highly technical study which often seems to sit at some remove from the mainstream of historical and archaeological research. One important aim of the chapters offered here is to show ways in which money can be incorporated into analysis of the Middle Ages more broadly, both for particular periods and in specific thematic contexts such as art, literature, and economic analysis. Case-studies, surveys and comments on critical literature all contribute to this end, and the book closes with a general bibliography that includes works selected by the authors as especially helpful and important.

With such a wealth of discussion of all aspects of medieval money elsewhere in the volume, the scope of this introduction is modest. It sets the scene on a basic level, examining some of the key terms, ideas, sources, and scholarly trends in the field from a more general point of view.

\section{Forms of Money}

Money in the Middle Ages meant many things. As in modern times, the same terms could be applied to coins, quantities of precious metal, and abstract values used to reckon credit and accounts, as well as goods in themselves or as substitutes for coined money. Some sense of this diversity is conveyed very well in Gaspar Feliu's contribution to this volume. The practical weaknesses of medieval money could also contribute to its conceptual strength: it is clear that across the Middle Ages, there was a strong tradition of thinking in terms of money, often in very subtle ways, even when actual cash was in short supply or unsuitable for the majority of transactions.

In an important sense, then, coined money is a small part of the story, although until the appearance of extensive financial records in the later Middle Ages it is the one which by default receives most attention. Pieces of metal stamped with a design that validated them as the trustworthy product of a 
given authority had been made for over a millennium before the end of Roman rule in western Europe during the fifth century. Even in northern and central Europe, coins had been minted and used before the coming of the Roman Empire. As such, the general principle of metallic coinage was deeply engrained in medieval Europe. It was not just a matter of rulers issuing coins to make and receive payments in a regulated fashion; coinage had become a hallmark of ordered society.

A time-traveller taking a tour of medieval Europe would have had a bewildering variety of moneys to negotiate. The details that he or she might have found in various periods and places are set out elsewhere in this volume in the chapters by Alessia Rovelli, Andrew Woods, Richard Kelleher, and Philipp Robinson Rössner. If travelling back from modern times, he or she would have noticed a lack of monetary means of exchange besides coin. People certainly thought in terms of coin for all sorts of purposes, but there was no equivalent to the credit card, PayPal, or the like. Instead, many transactions depended entirely on trust: buying things on a very simple credit basis, for instance, when coin was not available. ${ }^{1}$ This worked well enough in the small face-to-face communities in which most medieval people lived - any unpaid debt could easily be pursued - but it meant that travellers (not least putative time-travellers) often had a hard time and needed cash even more than others. ${ }^{2}$ Neither was there a widespread near-equivalent to the cheque. Ingots or objects of gold and silver fulfilled some of the same roles: with precious metals being so closely tied to concepts of value they were a natural form of storing wealth, and under some circumstances could serve as a high-value means of exchange. At times uncoined precious metal was used in preference to coin in exchange settings, as in Viking-Age Scandinavia, but it persisted alongside coined money on some level throughout the Middle Ages as a higher-value alternative. ${ }^{3}$ In the later Middle Ages, more formal written financial instruments started to develop, above all the bill of exchange. By the 14th century, merchants at the apex of international commerce could do most of their business without using coin at all. But there were important limitations to paper finance at this stage. It could not easily be transferred between parties other than those named in the document, and was concentrated in Italy, especially in the cities; elsewhere it spread slowly beyond outposts of the Italian banking companies. ${ }^{4}$

1 Bougard, "Le crédit dans l'Occident du haut Moyen Âge".

2 Naismith, "The social significance of monetization in the early Middle Ages", pp. 24-25.

3 Skre (ed.), Means of Exchange; Phillips, "The monetary use of uncoined silver in western Europe in the twelfth and thirteenth centuries".

4 Spufford, How Rarely Did Medieval Merchants Use Coin?. Cf. Bell, Brooks, and Moore, "The non-use of money in the Middle Ages". 
Under these circumstances the emphasis would have fallen on coins. These would have looked very familiar at first glance, and on a basic level worked in much the same way as those of the 21st century: they represented an easy, relatively reliable means of storing and transferring value. Yet on closer inspection there were important differences from modern currency. First, all medieval coins were handmade at every stage of the process, from the casting and carving of the die to the shaping of individual pieces of metal for striking. Hence, although a time-traveller would normally have found coins to be interchangeable in practice, there were small differences in appearance between them. Dies made by hand, even with the help of tools for repeated parts of the design or inscription, would differ one from another, as would the exact placement of the die on the coin (or "flan", the technical term for a piece of metal intended to provide the basis of a coin); so too would the coin's exact weight and fineness. Margins for error in all these areas were highly variable. Some coinages were very strictly controlled and look almost like the product of some kind of automated process; others are quite slipshod.

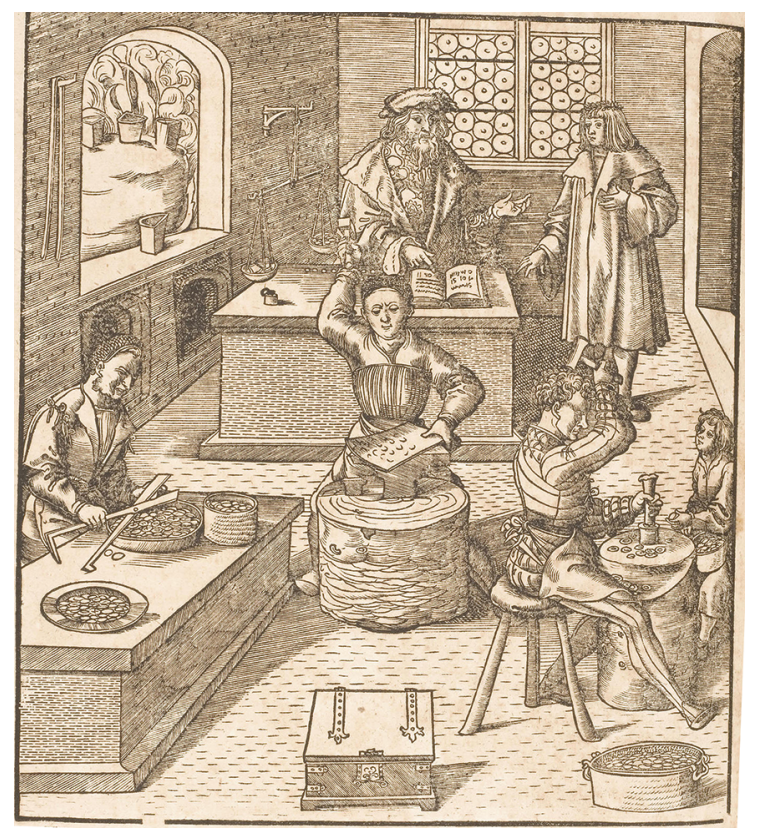

FIGURE 1.1 Woodcut illustration of a minting scene, from Emperor Maximilian I, Der Weisskunig. Originally executed by Leonhard Beck (c.148o-1542) in 1514-1516, but here reproduced from a printing made in Vienna in 1775 (p. 8o). SOURCE: UNIVERSITÄTSBIBLIOTHEK HEIDELBERG/CREATIVE COMMONS. 
The mechanisms behind coin production are vividly encapsulated by figure 1.1: a famous woodcut illustration by Leonhard Beck (c.1480-1542) made in 1514-1516 to illustrate Emperor Maximilian I's (1486-1519) manual on rulership, Der Weisskunig. This particular image shows the eponymous "white king" - who stands at the back, surveying the operation with a set of scales he would use for quality control - and the series of techniques needed to turn bullion into coins. One man in the centre beats a sheet of metal to the correct thickness; another to the left cuts a sheet into round pieces; to the right a third man strikes the prepared pieces of metal, with the help of a young boy who had the unenviable task of quickly removing and replacing each coin. All of these production techniques were centuries old by the 16th century, and can be paralleled across the Middle Ages. There were of course differences in detail. Some minting operations would have been much larger, and many much smaller: Michael Dolley believed that the small "mint" of the Isle of Man in the 11th century could have consisted of "two men and a boy". There were also technical variations. In late Anglo-Saxon and Norman England, something akin to a heavy-duty pastry cutter was used to cut flans out of sheets of silver. Some 7th- and 8th-century coins were made by striking uneven globules of silver, while 12th- and 13th-century "bracteates" were wide, very thin coins struck only on one face, probably against a soft surface such as leather. Nonetheless, the "white king's" picture provides a good (if rather formalized) impression of how medieval coins were manufactured.

In addition to finding medieval coins somewhat irregular physically, a timetraveller would have probably been struck by the widespread use of precious metal. This rarely equated exactly with the face value of coined money; if it had, there would have been a strong incentive to remove coins from circulation and melt them down for their bullion. Gold was prevalent in the immediately post-Roman centuries, as it had been in the late Roman era, because of the wish to maintain a familiar and prestigious currency integral to state finances. Our time-traveller would then have found a long era dominated by silver pennies, which first appeared in northern Europe late in the 7 th century and spread out from there to central and eastern Europe, Ireland, Italy, Scandinavia, Spain, and beyond. But he or she would also have noticed that as time went on pennies were generally of poorer silver - indeed, often virtually no silver. They were increasingly impractical for large purchases, and although gold coins and precious-metal bullion had always been available to some extent, demand grew for a more systematic monetary answer to this problem. If

5 Dolley, "A Hiberno-Manx coinage of the eleventh century", p. 83. 
our time-traveller had progressed into the 13th century, he or she would have encountered solutions in the form of larger silver pieces (the grosso, with its English equivalent the groat), along with gold coins such as the florin and ducat. Both these innovations began in northern Italy in the 13th century and percolated out to other regions at variable speeds; this explains why the later medieval monetary landscape was so complex, as increasingly differentiated monetary economies ran up against each other.

Of course, there had always been considerable diversity in medieval coined money, especially if one takes a broader view that incorporates the full extent of Europe and the Muslim world. There is no reason our imaginary time-traveller would have restricted him or herself to western Europe, and the foregoing comments really only apply to this area. A visitor would have found that native coinage appeared significantly later in much of central and eastern Europe and Scandinavia during the Middle Ages. This is emphatically not a matter of earlier polities lacking in economic complexity or wealth - far from it: Russia in the gth and 1oth centuries was a veritable Euphrates of Islamic silver, which flowed into and through the area in vast quantities. Rather, adoption of coined money was a cultural statement.

Meanwhile, in the Mediterranean, western Europeans travelling east would have encountered monetary systems that reflected not just very different cultural milieus but, for much of this period, significantly richer and more sophisticated economies. These included the Byzantine Empire, or rather what its inhabitants quite rightly still called the Roman Empire, which preserved a multi-tiered monetary system with a large gold element (central to its fiscal structures) until the 14th century. ${ }^{6}$ On the eastern and southern shores of the Mediterranean, there was a still larger and more diverse sphere: that of the Islamic Caliphate and its successors. These operated a currency which dwarfed that of early and central medieval western Europe in scale and complexity. As in Byzantium, payments to and from the state played a large part in driving the production of gold and silver, and copper alloy was also at some times used extensively for smaller-value transactions. All three metals interacted in day-today business. In the absence of a real-life time-traveller, one can turn instead to one of the many remarkable letters preserved in the "geniza" of the Ben Ezra synagogue in Cairo. In this chatty and meandering missive, an 11th-century Jewish merchant of Cairo gave specific instructions on how particular purses of money in the possession of his correspondent should be handled: one purse

6 Hendy, Studies in the Byzantine Monetary Economy c.300-1450; Morrisson and Schaaf, Byzance et sa monnaie (IVe-Xve siècle). 
of gold dinars (but not the one belonging to his mentor) should be used to make a payment, and it would be best if they could be changed into silver dirhams first - preferably low-quality ones. If the correspondent chose instead to spend them, handing over the proceeds later, he should buy flax. ${ }^{7}$ Some echo can be heard of the back-and-forth of letters, purses, goods, and anxiety that prevailed in the large and sophisticated 11th-century Egyptian economy, within which coined money played a critical lubricating role.

Coins from western Europe, Byzantium, and various Muslim states mingled in the Mediterranean. The prevailing currents that carried them in multiple directions are closely intertwined with underlying movements of people and commodities. Chapters in this volume touch on these questions of large-scale coin circulation, as does the wider literature on early medieval currency. ${ }^{8}$ All merchants shared a preference for precious metal in coins which would be used for long-distance trade: these carried enough gold and silver to make their transfer between different monetary systems practical, since in making that transition they usually became in effect small, round pieces of bullion. The validity of a coin, and the incentive to recognize it as a distinct piece of currency rather than a more or less pure piece of metal, depended on a combination of backing from the ruling authorities and acceptance among the intended users.

\section{Money and Authority}

Finally, a time-traveller accustomed to 21st-century coins and notes would have been struck by continuity in one aspect of money: reference to the ruling power. Names and images of kings, emperors, city authorities, and the like were virtually universal. These visual statements had been a commonplace of coined money since its inception in ancient times, and served ultimately as a form of guarantee, a pledge that the ruler would honour - and possibly compel others to honour - the piece of metal at a given value. The precious-metal content provided a counter-pledge against that guarantee.

Medieval Europe was heir to a very long and well-established tradition that tied the issue of coin to ruling authority. The most immediate and lasting precedent was that of the Roman Empire. Roman coinage would exercise a powerful influence on the visual and organisational aspects of medieval currency,

7 The letter is illustrated and translated in Goldberg, Trade and Institutions in the Medieval Mediterranean, pp. 58-61.

8 Grierson, "The monetary reforms of 'Abd al-Malik"; Spufford, Money and Its Use in Medieval Europe. 
seen in all sorts of areas: the strong attachment to verbal statements of position (normally, in western Europe, expressed in Latin); the way in which rulers were portrayed; and of course the general principle that kings and emperors should take charge of the currency. A second key ingredient that combined with the antique Roman tradition was Christianity. Deep-rooted Christian ideals affected ways in which money could be used, and these touched on coinage manufacture as well. Crosses, saints, and religious invocations became an integral part of the visual repertoire of coined money, alongside references to king, emperor, city, or similar. An excellent case-study of the numismatic conjunction of religion and power is presented in Anna Gannon's chapter in this volume. This focuses on early Anglo-Saxon England, a context in which the verbal element of coinage was minimal and the link with ruling authority probably more segmented. These qualities make Gannon's case-study an especially interesting and nuanced one to set alongside developments elsewhere in medieval Europe. Broadly speaking, the nexus of power and faith was prominently displayed through coinage. Rulers who sought to establish legitimacy often issued coins on the same model as their predecessors', in the expectation that they would project an impression of "business as usual" and thereby bolster their bid for acceptance. ${ }^{9}$

As might be expected, kings and others jealously protected rights surrounding coinage. It was for this reason that coins often carried a reference to the person or place responsible for manufacture. This part of the inscription was not primarily a statement of authority or power, even though involvement with minting could be prestigious. Rather, it was a sort of security measure: anyone who doubted the quality of the coin could trace it back to its point of origin, and if necessary hold its makers accountable. The manufacture of coin was generally restricted to places or people sanctioned by the ruler - even if, in some cases, the thread linking individual mint-places to the overall ruling authority became quite attenuated. France and Germany in the 1oth, nth, and 12th centuries saw the number of mint locations multiply and devolve into the hands of counts, dukes, bishops, and abbots, though many of these figures did so on the strength of a royal grant or (at least notionally) in their capacity as holders of formerly royal prerogatives. ${ }^{10}$ On a more pragmatic level, ferocious punishments lay in wait for those who challenged "public" authority through acts of forgery: heavy fines, mutilation, and death could all be meted out. Tellingly, less severe penalties were also instituted for those who rejected

$9 \quad$ Naismith, Money and Power, pp. 117-27.

10 Kluge, Deutsche Münzgeschichte von der späten Karolingerzeit bis zum Ende der Salier. 
legitimate coinage. Money and authority thus occupied a two-way street, involving the use as well as the making of coin. Rulers extended this principle to limit what kinds of coin could be used - typically those of their own territory, and sometimes only those of the current issue. This was the premise of what is known as renovatio monetae (renewal of the coinage), a system in which only coins of the current type were deemed acceptable and they had to be reminted from time to time - potentially very frequently. ${ }^{11}$

The imposition of a renovatio-style system highlights one of the recurring flashpoints of medieval coinage: how should the coinage be run, and for whose benefit? Rulers were expected to look after the interests of their people, and the provision of a reliable currency was part of that responsibility. Recoinage probably gained popularity as one weapon against the threats of forgery and inconsistency. ${ }^{12}$ But it could easily become a tool of exploitation if combined with hikes in the rate of profit taken by the minting authorities (known as seigniorage) and especially the imposition of debasement. ${ }^{13}$ This was a dangerous path to follow, for it could bring economic turbulence through inflation, and even damage trust in the coinage. Yet for kings in a desperate situation, the coinage might be too tempting a target to spare. Some French kings in the era of the Hundred Years War (1337-1453) fell back on exploitation of coinage as one of their primary sources of income. ${ }^{14}$ As might be expected, such policies prompted a lively dialogue about just whose good the money should serve, and what limits there should be to royal manipulation of the currency. The most famous text to emerge from this debate, "The Mint" (De moneta) by Nicole Oresme (d. 1382), articulated a moderate and responsible approach:

Although it is the duty of the prince to put his stamp on the money for the common good, he is not the lord or owner of the money current in his principality. For money is a balancing instrument for the exchange of natural wealth ... It is therefore the property of those who possess such wealth. ${ }^{15}$

11 Svensson, Renovatio Monetae.

12 Naismith, "The coinage of Æthelred II" examines one of the key periods in the evolution of this system.

13 The causes and consequences of debasement are a complex topic: for one major contribution, see Munro, "Coinage debasements in Burgundian Flanders, 1384-1482".

14 Sussman, "Debasements, royal revenues, and inflation in France during the Hundred Years' War".

15 Johnson, The De Moneta of Nicholas Oresme and English Mint Documents, p. 10. 


\section{Numismatics, Monetary History, and Beyond}

The leap from the study of coins to how they circulated is the point at which they become artefacts of monetary history rather than numismatics. The latter is understood as the study of coins in themselves. It is the expertise needed to classify and organize surviving coins, and involves the ability to weigh the significance of many different characteristics. Just looking at a medieval coin will betray some of its background, especially if it has an inscription. If it does not, working out when and by whom a coin was produced can be a challenge. It takes an expert numismatist to determine on the basis of minute variations in style and distribution of relevant finds that (for instance) a penny in the name of Æthelred II of England was actually made in Dublin or Scandinavia. Likewise, it takes an expert to know where to look for the small marks on gold florins of Florence or permutations in the lettering of later medieval English coins which reveal the inner workings of the minting process, and potentially when and by whom the coin was made. A practised numismatist will also be able to assess what the weight of a coin might indicate, or any number of other physical details such as weak striking (which can be difficult to distinguish from wear that occurs after production) or an unusual tone or texture. Even taste or the tone made when dropping a coin onto a hard surface can give away important details of its physical characteristics. As one might suspect, knowledge of this kind has a large practical element, and needs to be built up from direct experience of many coins. Good numismatists will be adept at integrating all these details into their historical context by fastening on the meaningful differences in practice between coinages.

Monetary history can be defined as study of how coins actually functioned in a social and economic sense. It requires looking beyond the coins as they are now preserved: in relatively few numbers, treasured by museums and collectors as remnants of a bygone era. To conduct monetary history, one needs to picture surviving coins as a tiny fraction of the currency that once circulated in the Middle Ages, a currency that played a very real and tangible part in the lives, businesses, and hardships of medieval men and women. The history of money thus involves coins, but has more in common with economic and social history than with numismatics. Estimating the original scale of coinage is one area of crossover between the two disciplines. Actual coins and calculations of output reached from the number of dies represented among them need to be placed alongside any surviving records of output. Monetary history can go in various directions with this data. One involves inserting estimates of productivity and the scale of the currency into a sequence alongside estimates of population and other critical economic indicators, to track macro-level 
developments in the economy. Another involves zooming in to a more individual level and examining how different people in medieval society actually used money, or what effect the nature of money had on their lives. How did peasants and paupers get by when only high-value denominations were available? How did everyone cope with periods when supplies of precious metal failed, as in the late 14th century? Several of these approaches are discussed in further detail elsewhere in this volume, not least in the chapters by Nick Mayhew on the larger-scale economic ramifications of coined money and by Rory Naismith on its usage within medieval society.

Many approaches to coins and money move beyond numismatics and monetary history as defined in these terms. Scholars are often comfortable combining the two, to good effect, and some of the best research within these areas takes account of other ways of coming at the subject. This methodological eclecticism is at the heart of the present volume. It sets out to give an overview of ways in which coins and money, as categories of object and thought, can be understood. As one might expect, there are many niches beyond the two traditional ones described above. An archaeologist, for example, will use coins in part as evidence for the dating and possible character of a site, but also focus on their importance as contextualized artefacts. Art historians place coins alongside other objects and images as representatives of visual culture rather than economic or physical entities per se. Cultural studies of coins as signifiers of identity likewise involve taking account of their appearance, but also indications of how they were actively used to build perception and understanding. Similar in some respects is the anthropologist's view of money, informed by a broad understanding of how it fits, comfortably or uncomfortably, into spheres of human interaction worldwide. Although grounded in observation of contemporary societies, anthropologists' and ethnographers' insights have played a critical part in forming ideas of how money might have been treated in ancient and medieval Europe. There are other ways of viewing coins, but these approaches are all addressed directly in this volume, in the chapters by (respectively) Nanouschka Myrberg Burström, Anna Gannon, Lucia Travaini, and Bill Maurer.

There are also important features of a coin that can be ascertained only by application of scientific analysis. Metallic content is one prominent feature which simply cannot be known in detail from outward appearances. ${ }^{16}$ There may be a veneer of finer metal on the outside, or significant variations in

16 Methods for assessing fineness are surveyed in Merkel, Silver and the Silver Economy at Hedeby, pp. 19-34 and 67-89. 
make-up across the coin. Determining what mix of metals is to be found in a coin requires skills that most numismatists do not possess, as well as access to up-to-date scientific equipment. A researcher trained in the use of techniques such as electron scanning microscopy or laser ablation analysis (among others) has much to bring to the table: in addition to finding out how "pure" a coin is in terms of main elements such as gold or silver, he or she can pin down what other elements are present in smaller quantities. The balance of these and specific features of some elements, such as lead isotopes, can give important clues to the origin of the metal. This information can only be pushed so far: it is difficult to make the leap from the metallic profile of a group of coins to a specific source, though it is normally feasible to say with confidence which coins do or do not share a common origin. ${ }^{17}$

\section{Source Material}

What are the actual underpinnings of all these approaches, from numismatics and monetary history to metallurgy and art history? Surviving coins are of course crucial, and can be understood on two main levels. They reflect, on the one hand, the production mechanisms that brought them into being, as outlined above; on the other, they reflect the acts of exchange that led to their deposition. Broadly speaking, the numismatist is more concerned with the former, the monetary historian and the archaeologist with the latter. Coin-finds and their assessment are a whole subject in themselves. They can be broken down in several ways, but three main ones are generally accepted: hoards, single-finds, and clusters of single-finds. ${ }^{18}$

Hoards are groups of coins (and often other objects) deposited together. For the numismatist, their value is that they provide a snapshot of which coins could be combined at one point in time. He or she can look at what coins are represented in a given find, relative to the entire corpus for that period: the latest one represented in it may well give a clue to when the hoard was deposited. The presence or absence of earlier or foreign issues might hint at how circulation was controlled, or at what kind of hoard this was. That said, the circumstances which led to any hoard's being abandoned and not recovered until modern times are inevitably murky and often contentious. A hoard might, for instance, be the result of gradual accumulation rather than a "scoop" of what

17 Merkel, Silver and the Silver Economy.

18 Grierson, Numismatics, pp. 124-39; Blackburn, "Coin finds". 
could be brought to hand in a single go, and its deposition could have been accidental or deliberate. "Deposition" is a word used advisedly, in an effort to be as neutral as possible. It is widely assumed that medieval hoards were concealed as a sort of safety deposit, with the expectation that the owner planned to return and recover it. Times of disruption (such as the Black Death, or the Viking campaigns in England in the later 9th century) do indeed tend to be particularly rich in hoards, for there was both more incentive to hide wealth and a higher chance of owners being killed or displaced. But while a general link between hoarding and times of uncertainty holds true, in the absence of exceptional circumstances it is dangerous to make a link between individual hoards and specific incidents. Moreover, other possibilities need to be kept in mind. Hoards could have been deliberately abandoned with no intention of returning - for apotropaic reasons, or to deny wealth to enemies, for instance. ${ }^{19}$ Deposition in an unusual location might suggest such a motive. Hoards could also be lost by chance. Even a bundle of medieval coins was a small object, liable to be dropped or misplaced.

Single-finds are more or less what the name suggests: individual coins found in an isolated context. It is thought that these represent losses in the course of day-to-day interaction (though of course the possibility exists of deliberate deposition, or indeed of an unrecognized hoard). They might be brought to light by pure chance (for instance, during building), by deliberate searching with a metal-detector, or by archaeologists in a controlled excavation. This last is obviously the ideal, for it furnishes some detail about the context of preservation. But responsible detector-users and casual finders record the locations of their finds with a regional or national repository of such information if one exists. An individual single-find is not especially informative, but a large number of them can begin to shed light on patterns of circulation. The information revealed by single-finds in this way is often quite different from what the hoard record suggests. The two categories of find were governed by very different forces: single-finds by what coins changed hands most frequently in a given area; hoards by (probably) the occurrence of destabilizing factors and by traditions of deliberate deposition. As such, single-finds offer a better window onto the role of money in the economy at large ${ }^{20}$ - though study of hoards, and the prevailing size among them, perhaps gives some flavour of access to coin. ${ }^{21}$

\footnotetext{
19 Remarks on the interpretation of hoards of Roman coins are also valid for the Middle Ages: Guest, "The burial, loss and recovery of Roman coin hoards in Britain and beyond", pp. 101-6.

20 Blackburn, "Coin finds".

21 Allen, "Coin hoards in England and Wales, c.973-1544", p. 151.
} 

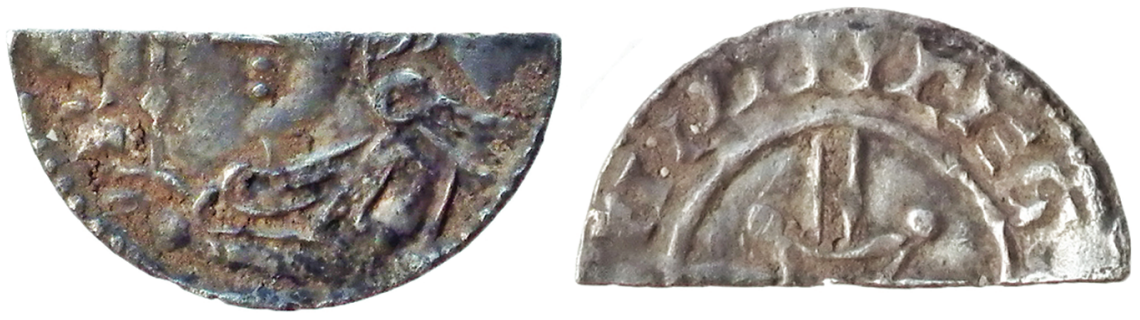

FIGURE 1.2 Cut halfpenny of Harthacnut (1040-1042), Winchester mint, uncertain moneyer, found at Kimpton, Hampshire PAS SUR-B55F52.

SOURCE: PORTABLE ANTIQUITIES SCHEME/CREATIVE COMMONS.

Clusters of single-finds are best treated as a slightly distinct category, even if they have much in common with those as discussed above. Above all, each coin probably represents an individual act of loss or deposition. Clusters of single-finds can occur in open ground or on the sites of meeting places or fairs (or, indeed, unexcavated settlements) uncovered by diligent metal-detector users. Places that have produced a lot of coins and other metallic items are sometimes referred to as "productive sites", in the absence of any detailed knowledge of their identity. ${ }^{22}$ Some archaeologically excavated sites also fit into this category, as do locations akin to the modern wishing well which attracted numerous depositions of coins for special reasons: the confessio Sancti Petri of Old St Peter's in Rome, for instance, where thousands of late antique and medieval coins left by pilgrims built up over time. ${ }^{23}$ Assessing a mass of single-finds from a single site is a delicate operation, for it magnifies some of the problems presented by single-finds as a whole. Were the coins lost soon after their date of manufacture? How representative is the profile of the cluster? With both hoards and single-finds, these and other challenges can be addressed only through careful comparison of all available information. ${ }^{24}$ That is to say, the entire corpus of find material often needs to be viewed as a whole.

As well as being artefacts of monetary production and circulation, coins are archaeological objects, items which were handled day in and day out by medieval men and women, and which often bear the imprints of such use.

\footnotetext{
22 Pestell and Ulmschneider, Markets in Early Medieval Europe; Coupland, "Carolingian single finds and the economy of the early ninth century"; the term is critiqued in Richards, "What's so special about 'productive sites'?".

23 Serafini, "Appendice numismatica”. See also chapter 13 by Lucia Travaini.

24 A case study is Blackburn, "Coin finds".
} 


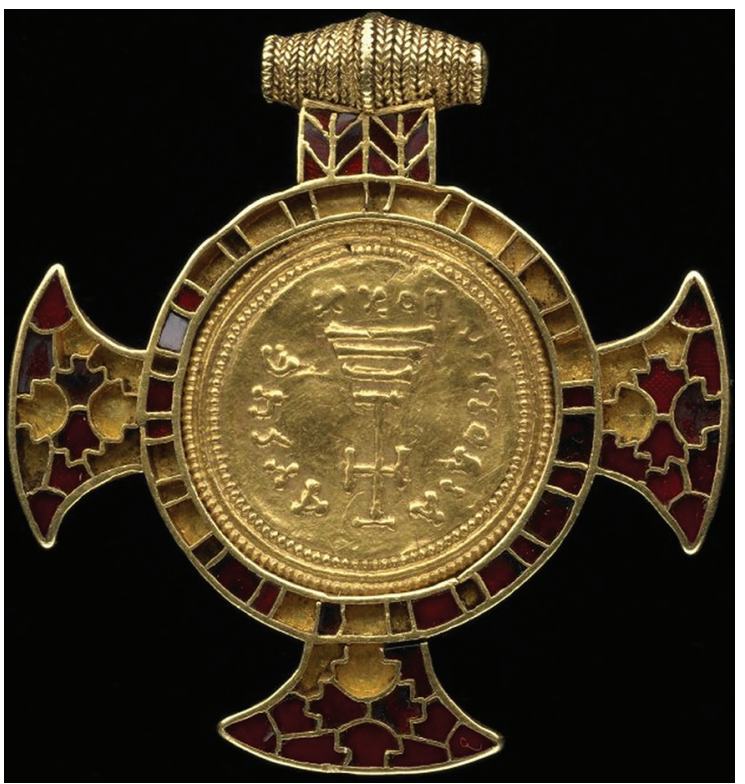

FIGURE 1.3 The "Wilton Cross", consisting of a light-weight solidus of Heraclius (61o-641), mounted in a gold cross inlaid with garnets, found at Wilton, Norfolk (now in the British Museum). SOURCE: BRITISH MUSEUM.

Their physicality is an integral part of their value. ${ }^{25}$ Has a coin been cut, bitten, or in some other way checked to assess its quality? If so, what does that suggest about the population's faith in the currency? In some circumstances, coins might also be cut into pieces for use as bullion or lower denominations. Cutting pennies in this way was the normal way of obtaining small change in England from the 1oth to 13th centuries (Figure 1.2). Coins might in addition be modified for uses which were not directly monetary - pierced, mounted, or otherwise adapted, often for ornamental purposes. This could be a multi-stage process: one Byzantine gold coin which eventually formed the centrepiece of a gold and garnet cross in 7 th-century England had not only travelled a long way from its source in the eastern Mediterranean, but had clearly been mounted in some other way before being removed and used to make the surviving cross (Figure 1.3). ${ }^{26}$ Sometimes even an unusual find context is enough to point to

25 In addition to the chapter in this volume by Nanouschka Myrberg Burström, see Kemmers and Myrberg, "Rethinking numismatics".

26 Archibald, "The Wilton Cross coin pendant". See also chapter 12 by Anna Gannon. 
special treatment of a coin. All such cases are crucial to understanding how money was seen and understood on a human level by its medieval users.

Finally, all students of numismatics and monetary history need to look beyond coins themselves to other contemporary objects that have a bearing on coins and exchange, such as hacksilver in the Viking world or cloth in later medieval Iceland, ${ }^{27}$ and above all to texts dealing with coins and money. These range from mint records which very directly address the matter of coin production, to charters mentioning preferred forms of payment, to anecdotes in saints' lives or miracle collections shedding light on how coins were used in practice and allusions in literary texts which illustrate deeper understanding of money's significance. The latter are discussed in an important and original chapter in this volume by Elizabeth Edwards, while aspects of money beyond coin are addressed by Gaspar Feliu.

\section{Scholarship on Money and Coinage}

The bulk of modern research into this subject is much more specific than the chapters contained within this volume. A high proportion of numismatic work is of necessity highly targeted, concerning an individual mint, reign, coinage, or similar. There is also a tendency for it to run along lines configured by modern national traditions. English numismatists think in terms of England and its generally quite centralized coinage; French numismatists think in terms of a sharp distinction between royal and "feudal" coins (i.e., those issued by non-royal authorities); while German and Italian numismatists only rarely think of Germany or Italy as a whole, and tend to focus on particular regions or cities. All of these approaches result from a blend of prevailing medieval circumstances with the evolving concerns of modern scholarship. Each subsection of the subject has its own preferred chronological breakdown, terminology, and lines of enquiry.

Research on monetary history, however, has always been marked by a strong comparative and international element, recently inspired by Peter Spufford's masterly surveys of money and merchants. ${ }^{28}$ The same is true in many other disciplines: anthropologists, art historians, and many others tend to have a wide-ranging conception of money. These approaches gain from the combination of depth, difference, and specificity offered by medieval material; equally, scholars who concentrate on targeted aspects of medieval money and coinage need to be conscious of the larger canvas to which they are contributing.

27 Hayeur Smith, "Thorir's bargain"; and Hayeur Smith, "Weaving wealth".

28 Spufford, Money and Its Use; Spufford, Power and Profit. 
Some impression of the scope of scholarship is communicated by the general bibliography found at the close of this volume, which assembles the key works thought to be most influential or useful in grasping the subject. It includes a mix of specific but exemplary studies, together with more sweeping works of synthesis.

\section{Conclusion}

The goal of this volume is not to fill every gap in scholarship touching on medieval money and coinage. Neither is it to survey any conceivable way of tackling the subject. Rather, it is intended as a form of invitation. Points of contact and dialogue are flagged up as authors address selected important aspects of the field in their chapters. If the book leaves the reader with as many ideas and questions as it does answers, it will have done its job.

\section{Bibliography}

Allen, M., "Coin hoards in England and Wales, c.973-1544", in J. Naylor and R. Bland (eds.), Hoarding and the Deposition of Metalwork from the Bronze Age to the 2oth Century: A British Perspective (British Archaeological Reports: British Series 615), Oxford, 2015, 147-65.

Archibald, M., "The Wilton Cross coin pendant: numismatic aspects and implications", in A. Reynolds and L. Webster (eds.), Early Medieval Art and Archaeology in the Northern World: Studies in Honour of James Graham-Campbell, Leiden, 2013, 51-71.

Bell, A.R., Brooks, C., and Moore, T.K., "The non-use of money in the Middle Ages", in M. Allen and N. Mayhew (eds.), Money and Its Use in Medieval Europe Three Decades On: Essays in Honour of Professor Peter Spufford, London, 2017, 137-51.

Blackburn, M., "The coin finds", in D. Skre (ed.), Means of Exchange: Dealing with Silver in the Viking Age, Aarhus, 2008, 27-74.

Blackburn, M., "Coin finds as primary historical evidence for medieval Europe", in S. Sakuraki (ed.), Dynamism in Coinage: Europe, China and Japan, Comparative Viewpoints. Proceedings of the 12th Conference of the Coin Finds Research Group Held in Fukuoka 2005, Fukuoka, 2005, 7-50.

Bougard, F., "Le crédit dans l'Occident du haut Moyen Âge: crédit, finance et pratique", in R. Le Jan, L. Feller, and J.-P. Devroey (eds.), Les élites et la richesse au haut Moyen Âge, Turnhout, 2010, 439-78.

Coupland, S., "Carolingian single finds and the economy of the early ninth century", Numismatic Chronicle 170 (2010), 287-319. 
Desan, C., Making Money: Coin, Currency, and the Coming of Capitalism, Oxford, 2014.

Dolley, R.H.M., "A Hiberno-Manx coinage of the eleventh century", Numismatic Chronicle, 7 th series, 16 (1976), $75^{-84}$.

Goldberg, J.L., Trade and Institutions in the Medieval Mediterranean: The Geniza Merchants and Their Business World, Cambridge, 2012.

Grierson, P., "The monetary reforms of 'Abd al-Malik: their metrological basis and their financial repercussions", Journal of Economic and Social History of the Orient 3 (1960), 241-64.

Grierson, P., Numismatics, Oxford, 1975 .

Guest, P., "The burial, loss and recovery of Roman coin hoards in Britain and beyond: past, present and future", in J. Naylor and R. Bland (eds.), Hoarding and the Deposition of Metalwork from the Bronze Age to the 2oth Century: a British Perspective (British Archaeological Reports: British Series 615), Oxford, 2015, 101-16.

Hayeur Smith, M., "Thorir's bargain: gender, vaðmál and the law", World Archaeology 45 (2014), 730-46.

Hayeur Smith, M., "Weaving wealth: cloth and trade in Viking Age and medieval Iceland", in A. Ling Huang and C. Jahnke (eds.), Textiles and the Medieval Economy: Production, Trade, and Consumption of Textiles, 8th-16th Centuries, Oxford, 2014, 23-40.

Hendy, M.F., Studies in the Byzantine Monetary Economy c.30o-1450, Cambridge, 1985.

Johnson, C. (ed.), The De Moneta of Nicholas Oresme and English Mint Documents, London, 1956.

Kemmers, F., and Myrberg, N., "Rethinking numismatics. The archaeology of coins", Archaeological Dialogues 18 (2011), 87-108.

Kluge, B., Deutsche Münzgeschichte von der späten Karolingerzeit bis zum Ende der Salier (ca. goo bis 1125), Sigmaringen, 1991.

Merkel, S.W., Silver and the Silver Economy at Hedeby (Raw Materials, Innovation, Technology of Ancient Cultures 2), Bochum, 2016.

Morrisson, C., and Schaaf, G.-D., Byzance et sa monnaie (IVe-Xve siècle), Paris, 2015.

Munro, J.H., "Coinage debasements in Burgundian Flanders, 1384-1482: monetary or fiscal policies?', in D. Nicholas, B.S. Bachrach, and J. M. Murray (eds.), Comparative Perspectives on History and Historians: Essays in Memory of Bryce Lyon, Kalamazoo, 2012, 314-6o.

Naismith, R., “The coinage of Æthelred II: a new evaluation”, English Studies 97 (2016), 117-39.

Naismith, R., Money and Power in Anglo-Saxon England: The Southern English Kingdoms 757-865, Cambridge, 2012.

Naismith, R., "The social significance of monetization in the early Middle Ages", Past \& Present 223 (2014), 3-38.

Pestell, T., and Ulmschneider, K. (eds.), Markets in Early Medieval Europe: Trading and 'Productive' Sites, 650-850, Macclesfield, 2003. 
Phillips, M., "The monetary use of uncoined silver in western Europe in the twelfth and thirteenth centuries", in M. Allen and N. Mayhew (eds.), Money and Its Use in Medieval Europe Three Decades On: Essays in Honour of Professor Peter Spufford, London, 2017, 1-18.

Richards, J., "What's so special about 'productive sites'? Middle Saxon settlements in Northumbria", Anglo-Saxon Studies in Archaeology and History 10 (1999), 71-80.

Serafini, C., "Appendice numismatica", in B.M. Apolloni Ghetti et al. (eds.), Esplorazioni sotto la Confessione di San Pietro in Vaticano eseguite negli anni 1940-1949, Vatican City, 1951, vol. 2, 225-44.

Skre, D. (ed.), Means of Exchange: Dealing with Silver in the Viking Age, Aarhus, 2008.

Spufford, P., How Rarely Did Medieval Merchants Use Coin?, Utrecht, 2008.

Spufford, P., Money and Its Use in Medieval Europe, Cambridge, 1988.

Spufford, P., Power and Profit: The Merchant in Medieval Europe, London, 2002.

Sussman, N., "Debasements, royal revenues, and inflation in France during the Hundred Years' War, 1415-1422", Journal of Economic History 53 (1993), 44-70.

Svensson, R., Renovatio Monetae: Bracteates and Coinage Politics in Medieval Europe, London, 2013 . 